\title{
Challenges for a future reintegration programme in Somalia: outcomes of an assessment on drug abuse, psychological distress and preferences for reintegration assistance
}

\section{Michael Odenzwald, Harald Hinkel \& Elisabeth Schauer}

Baved on an aciesment of aner 8000 ardine mililia member and military slaff in senen regions of Somalia, this arlide reforts on there groups of reypondemls woho mighl require special allewion in a fulwo Somali disarmament, armobilizalion and rimlesmliom (I)I)R) frogramme. $7 \mathrm{he}$

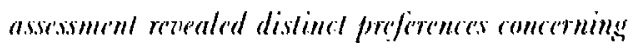
fulure minlegwation assislance, according to region. agr' ond ga'nder of lhe rrspondents. In the south of Somalia, a lange mumber of poung respondenls want to wlurn to formal schooling, bul they are especially burdened by zear related tratuma and exhibit. elonaled frallerns of druy use. Manv of the older respomdents in the north of Somalia and female

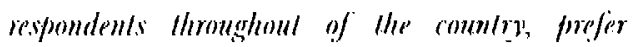
monelary supporl from a fulure reinlegrnlion programme. 'This group might not hane realislir expectations about demobilization and the existing modules of rinlegration assislante mightu nol meel their sperific meds. a third grouth romsisted of respondenls zillh a prior fosphologiand broakdoren

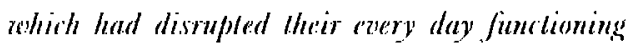
and zeso might be al high risk to develop severe psychialris disorelers in the future, as demonstraled in a provious stuly. 7 he findings suggest that, for planning and implementalion of a DDR forogramme, raviables such as the expertalions, drugs use and the psvchologiand siress of indinidual exrombalanls need to be laken inlo arrouml.

Keywords: IJI)R, demotilizalion, disarmament, reinlegralion, ex-combatants, micro level data, Somalia, khat, post trammatic stress syndrome: ( $P^{\prime}[\mathrm{SD})$, individual expectations

\section{Background}

Somalia is onc of today's most prominent examples of a "failed slale" (Cros, 1996), where: alter the fall of Siad Barre's dictatorship in 19931, the former allied rebel groups split ofl and iniliated a rivil war. This resulted in at lumbanitarian calasl rophe, with hundreds of 1homsands ol doaths (Arbeitsgemeinschafi Kricgsusachenforschung (AKUF), 2003), and millions of relugess and Internally Displated Poople (IDP) (UNHCR, 2005). Whil: the very recent upsurge of violence may hinder the peaceful development of the country, the reinstallation of a national government still nourishes new hopes for the peace process. It is estimated that in the commery as a whole; over 50000 militia are: curremly armed (World Bank, 2005). Their sustainable reintegration intocivil socic:ty will 
be: a major challenge in the course of the peace process. In this article, we want wo draw altention to the distinct expectations and needs ol the men and women comprising the armed groups in Somalia who will possibly be enrolled in a future disarmanent, destesbilization and reintegration (I)I)R) programme. With reference to our previous sludies and a large survey among lormer and active combatants, we identily distiuct stobgroups in diflerent parts of the coutry, dearacterize them by sociodemographic and psychological variables like expectations, drug use or mental problenus, and suggest measures for the planning and implementat tion of reintegration atssistance.

\section{The case for micro level data in reintegration programmes}

For various reasons, the reintegration phase of DIOR programmes is considered the most ditlicult sicp) (Collicr, Elliott, Hegre, Hoedller; Reynat-Querol, \& Sambanis, 2003; Mogapd, $20(04)$ and, as such, the batanee slenet revals successes and failures (Brosska, 1999). While evaluation of IOIOK programmes usually foeuses on macro level and programune related outcomes (Colletta, Kostuer \& Wiederholer, 1996), several rescatrohers clemonstrated recently the predictive power of micro level data for the reinlegration sucess of former combatants. Relevant characteristics of subgroups and individuals are, for example, the abusiveness of the ex-combatant's former rivil war laction (Weinstcin \& Humplureys, 2(1)(15), or the level of education ( $\Lambda$ yalew \& D)ereon, 2000). In our 2002 houschold survey in llargcisa, about seven years after the last civil-war-like violent outbreak in Somaliland, we found $16 \%$ of ex-combat ants continuously unable to participate in income genceating aclivities due to severe mental problems (Odenwald, Neuncr, Schauer, Elbert, Catani, Iingenlelder, Hinkel, Häfner \& Rockstroh,
2005) !. Wo (xplatined this high number with the very lenepuently observed exe'ssive khat use among former combatants, which is known to be related to the development of psychoric symptrms (Odenwald, 2(0)7). 'The leaves of the khal shrul, which contain the amphetamine-like cathinone, are traditionally chewed in $\Lambda$ frican and $\Lambda$ rab comt ries. In recent decades, the conomic importanes and consumption of khat leaves have increased dramatically while individual use patterns have: undergome prolound changes, from socially regulated to nucontrolled cousumption (Odenwald, 2007). In Somalia, the khat tade is reporedly among lhe means of income for civil watl factions, and combatants are frequenlysuppliced with lhe drug by their leaders (INN, 2003).

The high number of ex-e(omblationts being unable to reintegrate inte productive civilian life duc tovariatons on the micro level might considerably reduee the conomic dividends from the reinlegralion of former combalants to the whole country. 'lhus empirical rescarch and evaluation within DDSR programmes should focus on the ictentification of varialoles on this level, which are predictors or risk lawers for successful reintegration. and how reinlegration programmes can modily llems.

\section{Empirical assessment of micro level data in Somalia}

In order wo preparc for fiut um DODR activ it ies and to ielentify groups who deserve special attemion, in the second hatlol 20013 , a survery was carried out among active militiat memlers in seven regions of Somalia (1)cutsche Gesellsehaft für lechmische Zusammenarbeit (Goman lichnical (aoperation) Gol Is, $2003)^{2} ?$

Sanpling and participanks. Sampling involved a lhree-stinge process. In a first step, the seven regions were selected through expert ating 
in order to indelede the regions with the highest militia clensity. In order to set up the proposed cantomment phase acoordiug to Hhe recommendations of the Somali Natlional Reconciliation (anference (SNRC) al Mbaghlati, Nairobi, the regions chosen were where most of the encampment areas (87\%/o) lie. These: regions also included the major population and ecomomic centres of the country, as well as important rumal areass. In atch region, interviews were conducted with all bations whocollatomated. $A$ minimum of one entire unit within the overall struclure was completely asscosed, whereby militia leaders decided which anit was chesene. Ol ule major lactions, all but one collaborated with the researele projece

In the lhied step, all members of the appointed military/militia units were: approached and asked to participate in the intervicus.'

Strict random sampling in a survey concerning the very sensitive issue of demobilization in Somalia was nol feasible, $A$ detailed description of the sampling strategy is provided by Odenwald, Ilinkel, Schauer, Neuner, Schaucr, lillore \& Rockstroh, (sut)mitted).

In total, 872:3 militiamen and security stall were interviewed. 'The analysis included 8124 interviews of respondents $(93,1 \%$ \% had given lleeir consent to be interviewed and wholulfilled minimal standards (a minimum of 10 interviews per interviewer; forms completed). 'Tlec survey included less than $50 \%$ of all armed stafl in Somaliand and about $8 \%$ of the total estimated number of amed prisonnel in the rest of Somalia. Of these, 1070 belonged to regional atuthorities in Somaliand and Puntland, 2290) (o warlord militia, 1099) to frectance and rlan-batsed militia, 481 to Sharia court militias and 78 to business militias. Sociodemographic data are prescented in liable: 1.
The interziezer. Political leaders gare permission to participats: in the study during political consultations. Isocal intervicwer teams contacted the commanders of the selected units and appointments for interviews were made. Commanders were asked (o) intorm their unit members beforehand about the assessment. In other words, to report that the interviews were part of a preparatory activity for a future IDI)R programme agrecd on by their faction laders. (O) lhe appointed day, interviewers went directly into the compound used by the respective military/militia units to conduce the individual interviews. Interviews were conducted in a place that provided as much privacy as possible, such as in a scparate: room. Intervicwers informed participants before the intervicw about the purpose and method of the interview, about confidentiality and about the voluntary nature of the interview. linally, all participants were given atu opportumily lo ask questions. The interviewee gave consent orally belore the interviews were conducted,

Instruments. 'The guestionnatere used in the' atsessment was designed ats a comprelenensive and slandardized instrument. Questions and clesed answers were developed in English and translated into the Somali language according to intcrnational standards (independent back-translation). 'This was done by an interdisciplinary team consisting ol Somali and international experts on demobilization and mental health, health and gender. The information assessed comprised basic, sociodemographic variables, health status, preferences in an ceventual future reintegration programme, and indicalors of psychological dist ress.

Preference for reintegration assistance. Wt asked each respondent to choose two types of reintegration assistance modules out of a predefined list, which was explained to him/her 
Table 1 . Sociodemographic information on 8124 active armed forces and militia staff in seven regions of Somalia

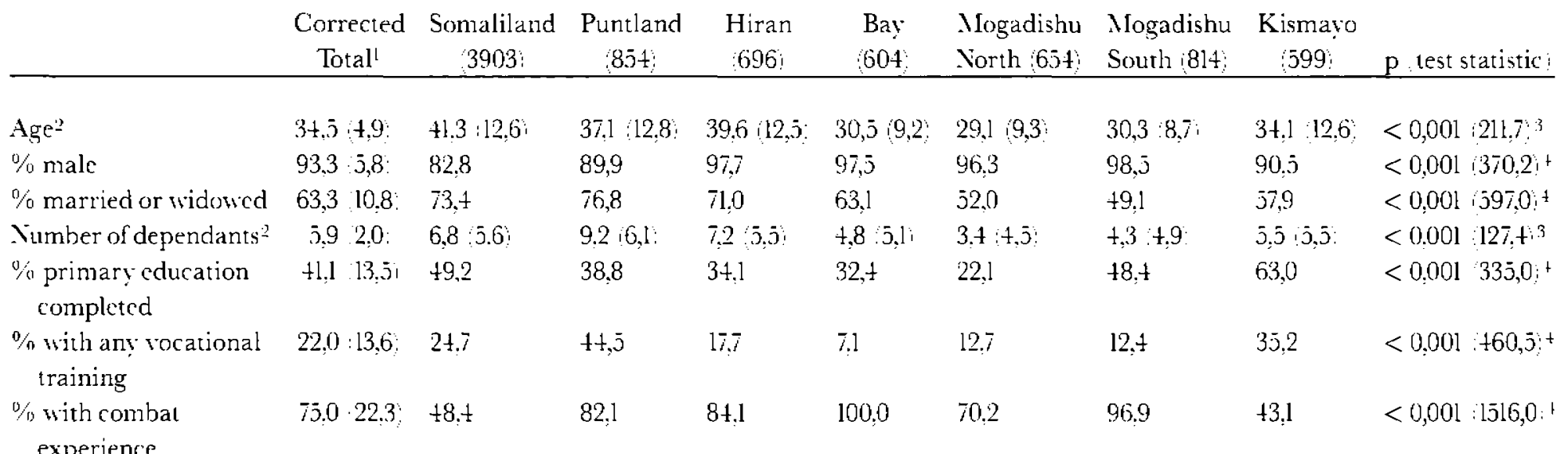

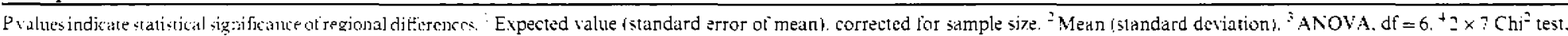
$\mathrm{di}=6$. 
by the intervicwer, a lirst and a seconel preference. Ithe list contatined: (I) return (o) formal coluation (sethooling, moiversity), (2) public works (occupation in labour intensive work programmes), (3) a job in the private security sector, (4) a grant in order to build u1) a new or expland an alleady cxisting small or micro anterpere (SME), (5) rearal integration as hereter or larmer, (6) training on the jols in private companics, whocollaborate with (he 1)R ? (7) participation in a vocallional training contse in order to acepuire specilie skills (clectrical enginerering, anuo mochanics, metal work, carpentry, masomry, handeralits, constal fishing, of her vouational training). (8) oflue form of atssist ance wished, and (9) no reintegration assistance:

Pspchological froblems amd rear related lrauma. Wo tried to identily respondents with a history of psychological problenes, by asking whether they had ever experienced a period of at least t werks wlen lley conld not work hecause of peychological problems, in a similar way to al previous study (O)denwald et al., 20(0)5). 'This way of assessing clisruplion of cerry day lundioning prover to be sensitive to detect scevere disorclers, such as pesychotic: disonders. 'Tramma was assessed by six ligglaly reliable itcms of the Somali version of the post tramatic aliaguostic: scale: (PIOS; Foa, 1995), which we hatel adapted to the Somali language, culture, and Islamic religion and "valualed in a previous study (C)denwald, lingenfelder; Sithauer; Neumer; Rockstroh, Hinkel \& Lillort, sulmitled). 'Tho Plos is a wiclely used selli-report instrument lor the assessincont of post tramatic stress disorcker (PISD) will good pxychometric propertie's and validity (Foa, Cashman, Jaycox \& Perry. 1997; Griflin, Ithlomansick, Resick \& Mechanic,2(0)4). 'The six items werealso used (1) asse'ss 'Partial P'ISI' (pP'ISI)). Against the: goold standard, P'l'SD diagnosis by a clinical interview using the Composite Inter- nalional Diagnostic Intcrvicw (C.II)I, Worlal Mrallh Organization, 1997) for pe'lsis had a specificity ol 0.96 (52 of 54 nom-P'l'SI) cases correctly detected) and a sensitivity of (1),55 (b of II P'ISI) (ases correctly dececed). ln summary, our neasure: on war related (ramma is reliable but produces a systematic underestimation of i rue P'TSl) prevalence.

Inlerviouers. Iraining and supenision: Interviewers were statlof local NC;Os with interviewing experience $(\mathrm{N}=38)$. Prior to data collection, a lA-day traning course was conducted in Hargeisa. Somaliland. 'I'he' training combancd introduction ol LDDR/ D)RJ' and clinical concepts, as well as rescarch design, interviewer training in role-play and field exercises, and preparation for the expected problems in the field. The supervision of interviewers in southern Somalia was realized throughout the assessment phase by satcllite phomes, radio and field visits by a Somali team member. $\Lambda_{11}$ intense awareness rampaign through the local press, radio and celevision prepared the: ground lor, and lollowed up, the ongeing operation with claily reporting. No sccurity inciclent was reported during the whole: of the assessment period. Alice the assessmont, local nomgoverumental organizations $(N(;)$ ) landed in the questionnaires at the (;'1\%" oflier in Hargeisa and assisted in dalla (indry.

Dala analysis: For ach region, we report the uncorrected cocfficients for proportions, means and standard deviations. On the level of the total population, we report coefficients corrected for sample size.

\section{Empirical findings}

Drug use: Based on this survey, we recontly estimated the use of six types of psychotropic and nareotic drugs among active and former combatants in Somalia: khal/miraa, hashish, psychoaclive: tablets, alcohol, inhalants, and 
bangi secods (Odenwald ril al., submiuted). Acoording to these estimales, khal is the: number one: drug over all of Somalia. ( )n average, in the week prior to interviews, respondents estimated that khal was consumed by $69,5 \%$ of their comrades (mombers of the same unit as respondent), hashish by $18,2 \%$, tablets by $14,4 \%$, alcolus by $8,2 \%$, inhalants by $3 \%$ and bangi seceds hy $1 \%$. There are significant regional dillerences in relation to perceived drug use: whereats in northern Somalia, khal was virtually theonly drug being consuned in armed lorces units, in southern and central regions, use levels of hashish and tablets reach alarmingly high levels.

Disability. psychological problems and war related trauma. About 12\% of the respondents reported that they had experieneed a serious war related injury at any time. $\Lambda$ t the time of the interview, over $10 \%$ of our sample. prescruted with anolnious pliysical handicap or impairnent, such ats a missing limb. Five pereent ol interviewees reported at least one period of psychological breakdown with the disruption of everyday functioning in their history. Sixty nime pereent of respondents reported at least me typical P'ISI) symptom: unwanted and int rusive memories of stressliul siluations, allempts (1) anoid them, sense ol a loneshortened future, clevaled jumpiness and sleeping difliculties. Partial P'ISI) (pl'ISI)) could be lound in $8,1 \%$ ol the respondents". In order 10 cope with their war related memories, $29 \%$ ol the interviewees reported that khalconsumplion helped to forget them.

Reinlegration ascistance proferences: The: $\mathrm{expec-}$ tatioms about, and prefercuces lor, reintegration modules revealed some: surprises. 'l'be: most frecuently seleceded lorms of lirst assistance: were: grants for small and micro interprises (SME) $(39 \%)$, the return to lomal education (28\%) and vocational tratining $(13 \%)$. $\Lambda$ s second choice, most frequently vocational training $(26 \%)$, grants for SME $(24 \%)$ and rumal integration (17\%) were selected. 'Ihus, I radiliontally' casy-(o)-apply tools, like rural integration and employment in llo private: secourity sector, wereonly prederred by a smatl number of militia nombers.

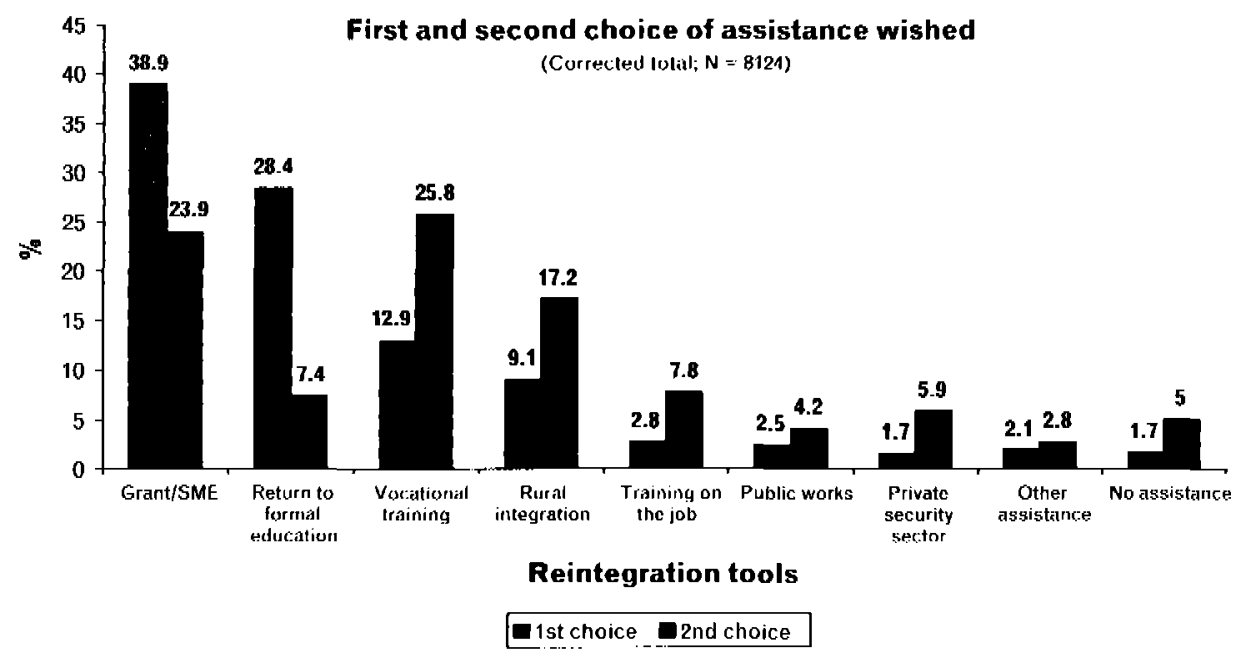

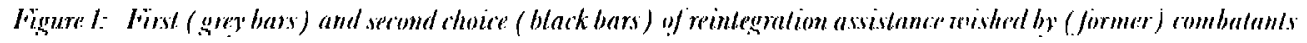
in Sommalin. Bars imdirate peremtages. 
'l'here were marked regiomal dillerencess related to the choices for reintegration assistance- In particular, lare number of respentdents who seleced the options grant for SME' and 're: urn to formal education'as first choice assistance, dillered greatly between regions. In the north of Somalia, a light proportion seteced the option 'trant for SMl:" (Somaliland 79\%, Puntand $5.5 \%$ ), in comtrast to the south (Hitan 40\%, Bay 9\%, Mogadishu, northern part 26\%, Mogatishu, southern part 28\%, Kismayo $42 \%$ ), in a total of +268 respondents. Amomg them, $17 \%$ were lemale $(\mathrm{n}=726$, or $82 \%$ of all female respondents), and a large proportion of this group refiesed to select any form of second choiec atssistatnes at all $(16 \%, n=671$ respondents). 'The preferences for "return to formal educat ion' (as lirst choice assistance) were the most frecuenty selected in some: regions of soullern Somalia (Bay/Bakond (69)\%, Mogadishu, morthern part 38\%, southerm part $4.5 \%$ ), in cont rast to the other regions (Somaliland 4\%, Punlaud 7\%, Hiran 12\%, Kismayo $23 \%$ ).

\section{Identification of subgroups with distinct needs}

In DI)R programmes, sceveral subgroups of bencelicharies are considered to have specific necds, such as: child soldiers (UNIC'EF, 2003, Kingma, 2000, Verhey, 2001), persons with disabilities due to physical handicap) or psychial ric disorder (Mogapi, 2004, (rear, 20)2, Bicber, 2002, Ayalew and Dereom, 200), Mchretcab, 20(2), lijgu \& (iccamu, 1996), or women, who had been part of armices or rebel groups (1)e Watteville, 2(0)2). Currently, best practice in 1)ISR requires the inclusion of components for these especially vulnerable groups (Colle'lla, 20)()).

Based on onr data from Somalia, we identified three additional subgroups of respondents, whe require special attention in the 1)ISR process. In lable 2, we display the sociodemegraphic characteristics of these groupss.

(iroup 1: Inrealistic expectations of monelary suffert. Jispecially int le north ol the commtry, and among the older and the female respondensts, a large number of individuals wanted money in the lorm of a grant lor a business (SMli). I'his might be related to the sociodemographlic characteristics of these respontdents, leing generally older than those who seleceded other reintegration tools, and being more ofien female, all of who might not find the oflered training modules, lomnal education, or making a new start ats herder or larmer to be adequate for them. Especially for women, sMli might have been the only reintegration tool they found acceptable. In accordance with the Somali traditional right, and in absence of public social seceurity systems, women frequently inherit paid posilions of deceased men and become part of the military units. In a lew cases, women had been active lighters during the liberation war, but mostly they had assumed other responsibilities within military and militia. units, such as cooking or cleaming. lispecially in the North of Somalia, a relatively high percentage of women areon the government payroll, and will be part of luture demobilization and reintegration programmes. 'Iradiliomally, women in Somalia have a weat position, which can be explained by 1.he: male: dominance within the traditional pastoral sociely. However, there are remarkalsle dillimences regarding women's social position within the country. Oflicially, it might be denied to women to hold land rights and possess businesses, especially in conservative and fundamentalist segments of the population. However, especially in economic centres, women are frepuenty economically aclive, as petty traders and shop owners, or in cooperatives, since they simply have to 
Table 2 Characteristics of three groups who deserve special attention in a future Somali DDR program

\begin{tabular}{|c|c|c|}
\hline Groupl: & Gromp?: & Group $3:$ \\
\hline Intrealistic & lommal education & alble to \\
\hline $\begin{array}{l}\text { expectations } \\
\text { (4083) }\end{array}$ & $\begin{array}{c}\text { and reintcgration } \\
\text { lailure }(14 \underline{2})\end{array}$ & \\
\hline
\end{tabular}

\section{Fixpectation lowards reintcgration}

Rogions

$\Lambda \mathrm{gi}^{*}$

$\%$ fimale:

$\%$ single:

Dependants

$\%$ primary education

$1 / 0$ any vocational training

$1 / 0$ p'ISI )

Nimber of trauma sympioms

(1) Paranovia

"\% sell-reported k/mat

use lasi worek

Quantity of sell-reported

khat use pere week

(users only)

$\%$ excessive that use amomg

chewers (>2 bundles/day)

last week

$\%$ self-medication

k.hal in units last werek

Hashish in units last work

'lablets in units last werk

Alcohol in units last. werek

$\%$ combat exposure

Age of lirst combat exposure

$\%$ severely wounded in war

$\%$ physical impairment

\section{SME}

Mostly North

$10,6(12,8)$

17,6

$1,3,7$

$7,2(5,6)$

46,0

25,8

2,8

$0,9(1,3)$

3.2

27,3

$8,7(11,5)$

24,3

9,9

$70,4(2,3,2)$

$5,9(1.5,6)$

$4,5(12,7)$

$3,(1)(9,(i)$

58,0

$24,7(9,0)$

16,2

18,3
Formal education

1)iverse

All the country

$3.5,6(11,4)$

4,0

39,1

$4,6(5,0)$

38,1

18,9

31,8

$3,1(1,6)$

15,2

52,2

$10,0)(12,0)$

$10,1(11,3)$

52,9

47,5

54,0

(i2, I $(31,(0)$

$15,8(2,3,9)$

$12,5(20,0)$

$6.7(16,0)$

76,4

$23,0)(9,7)$

$1.5,8$

17,4 carn an incone: 10 sustain the ir lamilies some with high levels of suecess. This secnario offers at loast some possibilities for reintegration modules for femalc benceficiaries.

'I he high number of beneliciaries who opted for monetary support probably also reflects inappropriate expectatlions concerning a DIDR programme, in the sense of seceing it as a chance 10 simply accuire a large amomo of money. In the Somali pilot DRP programme, SMli proved to be a relatively expensive reintegration tool, lecause gratus 
had to be suflicient enonght to chable the building up, or expansion, of a business and individualized solutions with a high need lor advisory services. Dare to the high costs and the limiterl number of popole ditting the required qualitiontion prolile, in future IOIR programmes, SME should only be: oflered to a small number of people who lielfil all precouditions. I lowerer, a future Somali IOIR programme nust also lake into account the needs of older and female participauts; allowating more resoureces to the average individual reintegration process in order to allow a grater proportion ol respondents to go through an SMli tool. Or; it could develop speceilic oflers for this target group, like vocational training lor females. At the same time, it has to aded ress unrealist ic expectations concerning monetary grants. Unrealist ic expertations may lead to difliculties in a fiulure l) ) $\mathrm{R}$ programme, and might ceren hase hloc porential to threaten the programume's primary goals. In such cases, lormex combatiunts feel betrayed or frustrated because they did not get as muclo money ats expected, and they might turn away from the programme, or resort co viokence. In light of the late that only a certain pereentage of patricipants of a larger D)DR programme. qualilies lor the participation in an SMEtool, and that a substautial proportion will have to be reintegraled into rural forms of subsistence, the communication and information about the dillerent reintegration modules will have to be very explicil and clear, and must be prepared and supported by a strong information and sensilizaton campaign. 'The selection critcriat lor participants of the SMli module should therelore bo losth stricl and transparemt to everyone. Simultaneously, the advantages of less 'popular' tooks, lor older participants, should be: highlighted. $A$ s criteria for SMli, ascertaining whether basic busine'ss skills al ready exist or (ant)e Irained, whe: her anceonomically promising business idea can be developed and whether lemale family members can be inclucled in a responsible position in SML projects will be needed. lixperience gained in an SMF support andivity by the I:G:/GI\% pilot ( $; 1 \%, 2004)$ projects supports this approach. (iroup 2: Psvchological problems and relurn loformal. eduration. lispecially in the south of the comery, a large group of young respondents sclected $1 \mathrm{l}_{\mathrm{s}}$ return to formal education as Meir lirst choice ol reintegration assistance. ( )nly 30 (2\%) among them were female: I'his group reported high levels of firepueme combal exposure, and wereon average lour yeass younger than the olher combatints at the: lime of their first combat expesure. Therefore, it was not surprising llat lhey reported trauma symptoms more frecpucully: 78\% compared to $47 \%$ in the rest of the sample. (p<,001). They were also more likely to qualily for pP'ISI). Additionally, they admited to chewing khat more often and to chewing excessively. What is more alarming is that lhey olien reported that khat would help them wo lorget stressful war related expericonces. In their units, we also found threefold higher hashish, alcohol and tablet comsumption compared to the rest of the sample.

In summary, this group showed alarmings characteristies on the micro level that suggest that a large percentage of them might be al risk of lailure in any reintegration programme; beause of high levels of psychological traumat and drug abusc?. Furthermore, we lomed that drug intake among llem olicen has the function of helping to lorgel lammalic: war expericnces (Kulka, Sifhlenger, Hairbank, Hough, Jordan, Marmar \& Weiss, 1990). Sclf-medicalion of P'lSil) symptoms by khal use an probably be cxplained by the alleviation of depression-like sympons as described for traumatized amphetamine users in western 
countries (Jrady, I)ansky, Somme \& Saladin, 1998). However, in the light of recent studies, which also suggest that the intake of khat is related to increased aggressive behaviours (Banjaw, Mic\%ek \& Sihmidt, 20066), we may cxpect that the: frecuest khat intaks: might also lead to more aggressive hehaviours among this group (Beckham, licldman, Kirby, Hertoberg \& Moore, 1997). 'Thus, war rclated trauma and coping with it by using drugs can, on the one hand, be a starting point for the development of other severe psychiatric disorders, like drug dependency or drug-induced peycho(ic clisorders (Chilcoat \& Breslau, 1998). (N11 the other laund, il will also protsably be related to behavioural problens during the reintegration phase, such as low sell-eliscipline, low frustration tolerance: with related outbursts of anger, or concent ration dilficulties (Mogapi, 2004). 'The high percentage: of respondents who use more than two bundles" per day, and the frequent use of benzodiazepines resemble the typical amphetamine drug abuse pattern found in western countries where, in order to cut down the: stimulating effects, users take tranpuillizers. 'I he experience from an electrical enginecring traning activity by an li(:/Gr/\% DRP pilor projece in Somaliland (G'l\%, 2(0)4) conlirms that a number of participants will not be able to follow the course cluc to these problems. Thus, we strongly suggest that a reintegration programme should consider special preventive, rehabilitative, psychological and medical assistance tools for these: who are alfected by drug and trama related problems in order to avoid reinlegration failures. The experience from western countries concerning counselling and prevention might be applicable only to a limited exteru as the cultural backgrounds dilfor significantly. 'Thus, we recommend that a future Somali DDR programme should include: comcomitant reseated activities with the aim to develop, actopl aurd evaluate trauma and drug related measures.

(ironp 3: Respomdenes al risk of deztoloping chromic mental disorders. In all DOIR programmes, bencliciaries presenting will a clisability dese 10 war related injuries or chronie nental disorders have to be expeced. Usually a referral system is recommented, which will give them aceess to a social security service and, especially for older ex-combatants, a pension scheme is introduced to secure their livelihood as obluer lome of econennic reintegralion into civilian seriely might not be: applicable: (Colletla ed al., 1996). However, at this time, a referral system and public social services are nonexistent. ( )ur findings show that about $5 \%$ (321) ol the respondents have: had a psychological breakelown in the past that led to the disruption of limetioning lor at lease 4 wecks. lifity perecont of them indicated that they experieneed their last mental breakdown alier lle year 2000 (range 1974 2003). They did nol reveal higher rales ol war related physieal injuries or impatiments. However, they reporeded al high tramma load, had elewed khal very lonequenely in the previous werk, and congaged in scll-nedieation of war related memories by khat use. 'The rate: of respondents with paramoid symptoms was more than three times higher among these respondents than among others?. 'l'he high rale of paramoia and khat aluses, which is related to the development ol psychotic sympenus, is in line wills our study in Itarghlecisa (Odenwald (et al., 2000.5). This study showed a laat peychot ic disorders are highly frectuente antong the chromically impaired ex-combalants. 'This group did not reveal dillerent expectations about reintegration compared to the rest of the sample: 174 selected a grant for SME: and 47 ehoose the return to formal education as their lirst preference. 
Nilwough currently they cannol be: contsidered disibled, they might be al risk of developing severe mental disorders in the conses of the diflicult aclaptat ion to civil life, and some of them might not be stable comougl to participate without medical assistatuce in standard reintegration tools. Psychiateric research has shown that copecially those: who were affected in the past are al high risk of developing psychiatric problems in the future. During theconflict, and in iumedialce post watr situation, vulnerable individuals might still be alske to finction. However, during the course of reintegration, after loss of stallus and the dashing of hopes and wishes, as well ats beingre confronted with coryday dilliculaies and resentments in the communities, lhey might not be able to deal with trannatic nemorics, and therefore may develop deperession and engage more in sell-nuclication by drug alsuse. In particular, the rhronic abust of khal, with its debilitating behavioural eflects (Odenwald, 20(07), might constitute: a diflerence: 6 other postconflict countries, alt longht the mechanisms are net well understond. Some time alter the ir demolilization they may still develop a chronic mental comelition.

The: number $(5 \%)$ we lound in this study is sulsstantially lower than the $16 \%$ of $\mathrm{c} x \mathrm{x}-$ combatants with chronic montal disorders who were incapable of participating in income geconcrating activities for years, which we laad found in our previous assessment in Somaliland (Odenwald a al, 2005). This discrepancy is in line with what one could expece lor a variet y of reasons. Inour Somaliland study, we: used a householel survey to identily ex-combatauts, a way of sampling, which includes those: who dropped out of service becaluse of mental problems. lurthermore, we might not have detected all vulnemalble individuals in this assessment, and it is probalbly impossible to identify all of them. Where their number is as large as in Somaliland, it would reduce the returns of demobilization substantially. Consequently, a IOIR programme should engage in preventive measures, such as education on psychological problems and direcions on where to find assistance $\Lambda s$ an investment in developmental assistance, a programmo should also initiate a follow-up) and support struclure, like a governmental department ol veterans' atlatirs or healh department within a veterans association, where they (a) access assistance and treatment. In this respert also, concomitant longitudinal researeh is highly recommended. We would also recommend that a future $1010 \mathrm{R}$ programme be linked to broader developmenual aclivitics, such as the recomstruction of medical services in the country.

\section{Discussion and recommendations}

Wo have reported some of the lindings related to expectations and psychological stress among participants in an eventual fiture Somali lol)R programme. 'These findings lighlight special considerations that should be: given to certain groups. Among them, a group of older and female: respondents wilh unrealistically high expectations aloout al DDDR programme, especially related to monetary grants. We sec the danger that they might not find it casy to participate in other standard reintegration modules, and that they may fecel easily frust rated in the course of 1)I R. Secoudly, a group ol young respondents, especially in the south of Somalia, want to comtime their formal cducation in the course of reintegration into civilian society but who display high levels of war related trauma and abuse of drugs including khat. They are at risk of developing behavioural problems in the course of reintegration, such as low frustration tolerance: 
and aggression, low disciplinc and addiclive behaviours, which all lcad to increased risk of reintegration failure. I aststy, a number of bencliciaries are al risk of developing severe psychological disturbances in the course of reintegration into civil society, especially as some of them have already experienced one or more episodes of psychologic al breatketown in the past.

Will respeet to ex-combatants who are disabled duce to physical handicap) or chromic psychologial problems, factions might use a DDR progranme 10 get rid of the responsibility for llem. Possilnly this group will not be apable of participating in standard reintegration tools, or maty not be alse to assume meaningful roles in civil society. llowever, the exclusive locus on referral systems to public health, social wellare and pension schemes, ats ratized in other 1 )I R programmes, needs to be avoided from the point of riew of sustainability due to linnited government budgets. Instead, assistance: to their next of kin might be an alternative way to secure their livelihood especially in the Somali socicty in which the extended family traditionally takes over the duty ol caring for weaker limily unembers. The formor EC: funded pilot DRP in Somaliland hat started to consider these dimensions and has already piloced sone modules to offer a variety of trainings and comoselling services wo caretakers of ex-combatants with chronic disability who, in turn, wore contmitted to caring for them (C"I\%, 2004).

()ur study hats some: limitations and the interpretation of single results must be dome with caution, especially as we and within a highly sensitive: lield (Grosse-Kettler, 2004). The sell-report datat on drug consumption and psychological symptoms is probalbly biatsed through a tendency to under report, as our previous experiences in Somaliland (Odenwald (e al., silumited) elearly showed.
( )n lhe ollere hand, estimations alound diug use in militia/military units might be allected by over rating, as shown in western scttings, or by moler reporting dac an religious norms, cte. The assessment of expectations towards reintegration assistance provicled by a fiture 1 DDR programme is also probalbly influenced by the high attrativeness of mometary support, so that other less altratelive but more realistic tools, are not considered. Although we trained interviewers (o) explain clearly that participants of the sludy will not have any atvantage in a fiture DlDR programme, we might still have inadvertently raised expectations and influenced responses. In gencral, the assessment of psychological varialbles in this context is anything but a trivial motertaking. fiurthermore, becaluse of the information policy of collaborating lections we do not know the actual number of armed persomed in the included units. However, due wo the liect l hatl all umil members were ordered to sere our interviewers, and the low rate ol breaking up, duc: lo large numbers and the inclusion of all lactions bul one, as well as the high motivalion to participate in the assessment, we argue 1 hal we managed lo achievea represemtative sample. This is further strengthened by the sulestantial variation we have in our datat showing that our sample isnt at highly selected homogeneous sulgronp), lasily, due to security reasons and other restrictions, it was not possible lo stepervise and support interviewers on a daily hasis doring the assessment. Yet, the liat that several hundred respondents admited that alcolool intake would exist in their localily indieales ale authent ie ity of the responses.

future studies necel to assess, in parallel, the validity of any kind ol data gat hered by using an objectiote critcrion (such as urinc drug screconing orl by validat ion intervicws) all least in a sulsample of respondents. Controbled 
lomgitudinal studies the only way of iclentily predictors and risk lactors for successlul reintegration on the micro level ancespecially neceded.

\section{Acknowledgement}

'The anturs would like to expmess theie apprectiation to Dr: Palicenes Lamam ( ) ayul, University ol Mbatara, Uganda, for lue laclp

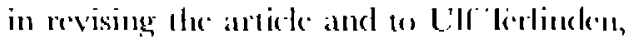
Liniversity of Bomn, (Fermany, and the

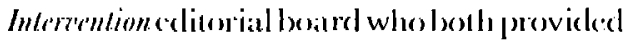
usclul comments on sperilic: issues, structure ind style ol"ihisanticle.

I In Sonnalia, most penple- in marel al morental

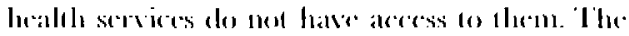

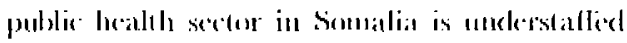

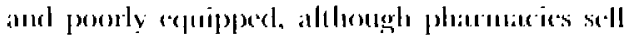

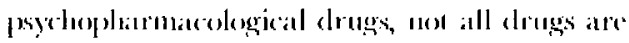
araibalse and the supply might be interrupsted.

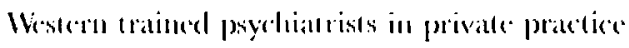
wotk in the higger cilies. For average Somalis, this treatument is motlordable, thoughto. Insteat,

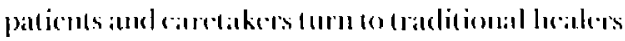
and sho iks ( Islam ic localess) in their commumilies

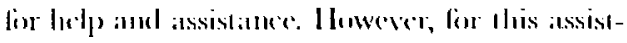

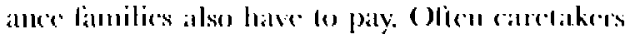

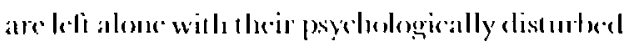

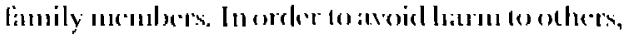

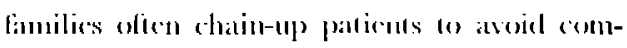

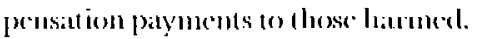

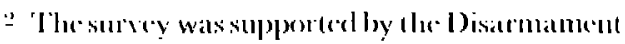

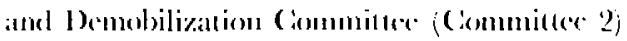

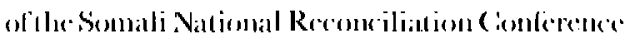
in Mlbighati, Nainolsi.

; In the morth of Somalia, Sommaliland and P'untland were seleceled as both regiens hate a strumg state-like power in the lomm of regiomal achministrations, In andal Sentalia, Hiran was douson and in soutluom Somatia, Bay/Bakonl, Mogaclishu and Kismayos. Megadishu was slivided intos Ino parts acoording wo lle: "grecen line:" which divides

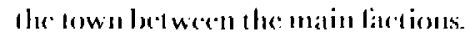

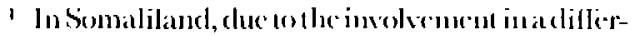
r.nt projece, a census-like assessument was intenderol. IJus, wo systemationally assessed all military units llate were indiated by the governneme of the autemomons regions Somaliland (north-west Somaliaj-

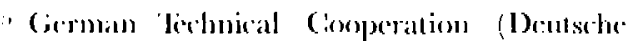

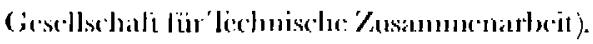

" I'he rader is advised that not all V'l'SI) symploms finmel cau be attributed fo trammatization during was. We have to expect that there is a substamial pre-wat bastlime of tratumat related pisychological problams.

7 Vole Inat our measure of plolsD underestimalles 1lu true prevalemes of Prlsis.

" Baserel on resulesola Kinyan study (I)hadphala. \& (Omole. 1988) we define the use of mone than

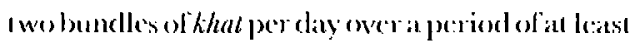
onc wock as dangerous.

"None that we assessed only paranesid thinking, a smatl part of the possible syumosom range of psychotic patients. 'Therelion, we underestimated the true prewaleme of psychotic sympens.

\section{References}

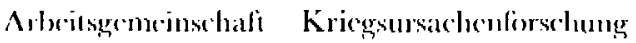

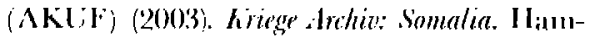

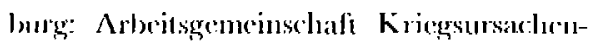
lorschung der Coniversität Hamburg.

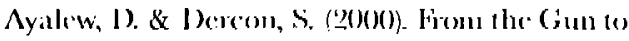
Hae Plough: abe Marro- and Microldevel Impate of Demolilization in Eshoppia. In: Kingma, K. ( lis]) Demolnilization in Sub-Saharan yrica. landon: Macmillan.

Baujaw, M. Y. Miczek, K. \& Sithmid, W.J. (2006). Reparalal Catha codulis oral aclministration culauces the baseline aggressive behavior in isolated rats. Foumal of Neural 7ransmisciom, $/ / 2(5), 51: 3-5.56$.

Brekbam, J. C. licklman, M. L. Kirloy, $\Lambda$. C: Hertaber, M. A. \& Mocre, S. 1). (1997). Interpersemal riolence and its contrelates in Vietnam 
vetcrans with chronic post ranumatic stress disorder. Journal of C.linical lswhology, 53, 85.9-8369.

Bicber, B. (20)2). Wie Kriege enden, Hamburg: Verlag l)r. Kovac.

Brzoska, M. (1999). Military Comversiour: 'I'lı: Balance Sheet. Journal of Prace Researrh, 36; 1:31140.

Brady, K.'T., Dannky, B. S., Sonne, S. (. \& Silatuliu, M. I. (1998). Post traumatic stress disorder and cocaine dependence. (Order ol onsel. Ameriscan Journal of Addiction, 7, 128-135.

Chilcoat, H. D. \& Breslau, N. (19998). P'ost t raumantice stress disorderandd rugedisenders: (cstinge anusal

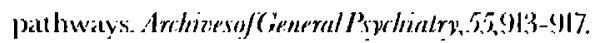

Golletta, N. (2001). World Bank, Dconobilization and Social Reconstruction. In: Bentwell, J. \& Klare, M. T: (Lids.) Lighl IVoapons and ciunl

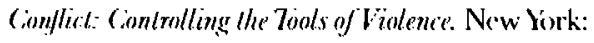
Rownan \& Lillkefielel Publishers.

Golletta, N., Kustiner, M. \& Wicderhofer, I. (19)96).

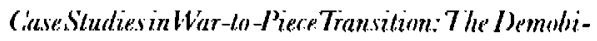
lization and Reintegration of Ex-Combatants in Eihtopia, Namilia and Iganda. Wishingrou, D. G.: World Bank.

Collier, P., Filliott, V. I., Hegre, H., Hoceller, $\Lambda$., Ri:ynal-Qucrol, M. \& Sambanis, N. (20)(3) Breaking the Conflid Trap: Cizil War and Derelopment Policy. Oxford: Oxford University Press.

D. Walleville; N. (2002). Addrewing (jender Iswes in Demobilization and Reintegration Irogrammes. Afrie Region Working Paper Series No. 33. Washington, 1).C.: Worldtsank.

Dhatplelalc, M. \& Onolo, O. E. (1988). Psychiatric morbidity annong khat chewers. Last African Mediral. Fourmal, 65, 35.5-350.

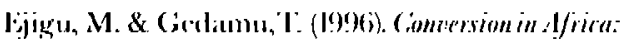

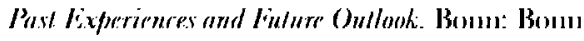
Intcrnational center fer Comersion.

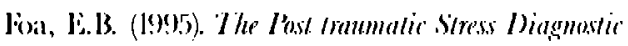

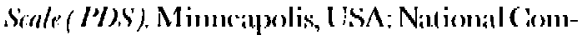
pulet Systems.

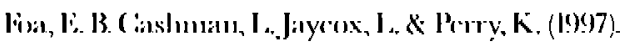

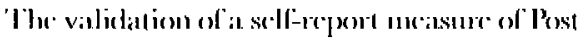
1raumatic Stress Disoreler: The Post trammadic Diagnostic Scale. Psychological Aswessment, 9, 1.15151.

(icar, S. [2002). Whishing as atrow: Chullenges facing

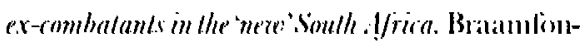
tein, South $A$ frica: Genter lin the Study of Vir)lence and Reconciliation.

Griffin, M. (., Lhhmansick, M. II.,Resick, P. A. \&

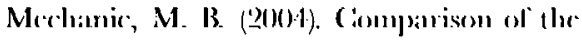

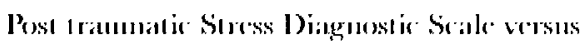
the CInician-Arlministered Pest trammatic St ress Disorder Scale in demest ie violenere sur-

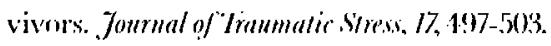

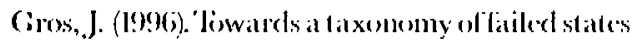
in the New World Order: decaying Somalia, liberia, Rwanda and Itaiti. Third Ilarkd Qualerly, 17, 155-172.

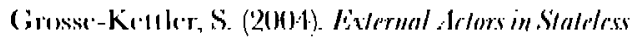
Sommlat BIC C: Paper. Bonm, Giomany: Bonn International cicenter for Comersions.

(i1)/ IS (200)33). Repont of thr. ford finding mission in Somaliu. Nairobi: (1\% in press.

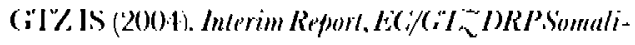

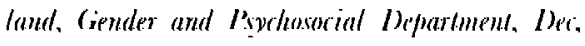
2003 April 200\%. Naimoli: ('I"\%.

Kingma, K. (2000). Dremobilizalion in Sub-taharan Africa London: Macmillan. 


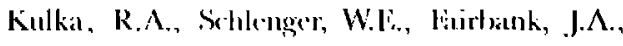
Hough, Jorda..1, Marmar \& Woiss (1990). Frnuma

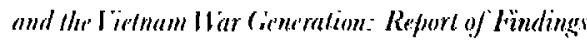
from the National IThlmam Valerans Readjustment

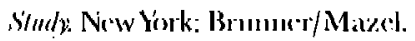

Mohreceal), A. (20)(1)2) Viteran Cambalomls do not

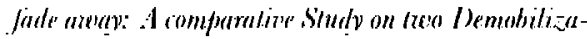
lion and Reinlegmlion Exorcises in Lrilrea. Bonn: BIC ( :

Mogapi, N. (2004). Reintegration of solelices: I the missing pierce Imemention, ?, 921-2025.

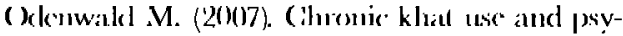

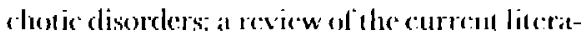
lure and future prospores. Shath, $53,9-22$.

()denwald M., Hinkel II., Silanuer li., Neumer li,

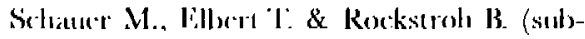
mitede. Sill-reported khat use atul opinion abeut clruge comsumption amome active: military personuel in Somalia: a cross-sectional study. PIOS M Ledicine.

()denwald M., I ingendideler B., Sichaner M., Nemere J', Rockstrol, B., Hinkel H. \& Elbere T. (stominiled). Srowning for I'ost tramallic Stross Disorderamong Somali cx-combatants: a validationstudy.

Odenwald, M. Nelumer, li. Sihauer, M. lillowe; l: R. Gatani, C: I ingenfelder, 13. IIukel, H. Haliner,

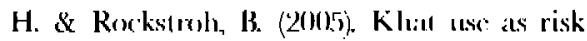
lactor lor psychest ic disorders: $\Lambda$ crossi-secclional and case-control study in Somaliat. BMC: Medicine, 3,5 .

IN (2003). Report of the l'amel of Expers on Somalin l'msuant to Security Coumcil Resolution 1925 (2)(1)). New York: United Nations.

UNHC:R 22(005). 200)t lilobal Regusere Trends. Gencvit: UNIIC:R in press.

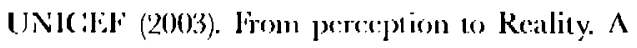
sludy on child protection in Somalia. Nairobi; uNIC:Lit Somalia.

Verhey, B. (2001). (ihild Soldiers: I'requenting, Demobilizing and Reintegrating. Africa Region Working Paper Sories No. 23. Washington, 1).(2., World Bank.

Weinstoin, J. \& Humphreys, M. (2005). Disentansling the determinants of sucresyful demobilization and rinlegration, Working laper Number 69) Siprember 2005. Washington, I).Ca: Cicnler lor (ilobal lovelopment.

World Bank (2005). Additional Arlimilies Note on Somalia. Washington, D.C.: 'l'he: World Bank.

World Health Organization (1997). Compesile International Diapnostic Interviea (CIDI): (are yersion 2.I. Gencva: World I Lall l, Organization.

Mirhuel Odenwoald, I) rer. nal., Dipl. Psyrh. aerorks as a clinical psychologist al the Inizersity of Konslanz, Cormany, where he is a therapist and researcher of an oulpalient clinic for refuges. and research zeard for Schizophrenia. In the course of his doctorale studies, he has done extensive fieldwork in the Somalia filot I)IR frogramme. email: michael.odenteald (ci) umi-konslanz.de

Harald Ilinkel, PhD was the head of (rT> IS I)RI' in IIargeisa, Somaliland, and currently works for the World Bankis Multi-Counlry Demolbilization and Reinlegralion Programme ( $M I I) R P)$ of the Crealer Greal Lakes Region in Africa, ('oma, Democratic Republic of Congo. kliwabolte Schauer, MA, MII zeorks woilh the international $\mathrm{N}(\mathrm{O})$ vito. She currently aordinates the arlinitias in norlhern Sri Lanka and Iganda wilh a main focus on the building-up of a sufporl infrastructure for wear-lraumalized children and their families. 